\title{
Strategic (spatial) planning approach in Turkey: new expectations
}

\author{
P. Ozden \\ Department of Public Administration, Istanbul University, Turkey
}

\begin{abstract}
The 2000s have been the years when comprehensive changes have begun to be lived in terms of public administration and planning. Legal formations realized in this short period of time have strongly modified the contents of public administration and planning, and have revealed new expectations. At this point, both urban planners and local governments have started to review their point of views about planning. Today, the fundamental actors of urban planning in Turkey query themselves and the legislators as to whether the concept of strategic planning can be a magic wand for the planning systems of Turkey, which has continued in a problematic manner since the very beginning. Within the scope of this study, questions such as the meaning of the concept of "strategic plan", its legal basis, and the new urban order that it shall create shall be analyzed.
\end{abstract}

Keywords: strategic planning, sustainability, governance, Turkey.

\section{Introduction}

When the few and very elementary experiences of the past are left aside, it can be suggested that Turkey has once again got acquainted with the concept of strategic planning during the last one or two years. The laws made one after another after year 2004 granted many institutions with the authority to make strategic plans. Based on this authority, the major institutions of urban management started to prepare their strategic plans. However, certain problems arose at this point. There were sharp differences between the mentality of strategic planning set forth by the laws and the policies and the implementations maintained by the institutions. Furthermore, this situation also caused a 
contradiction with the thought of establishing sustainable urban policies. These problems made it necessary that strategic planning be discussed once again and in detail.

In this study, the concept of strategic planning shall be described briefly once again and then the process of development of the concept of strategic planning in Turkey shall be reviewed; its meaning shall be analyzed and then strategic planning experiences of different metropolitan municipalities in the country and the results of the research shall be brought up. The study shall be completed with evaluations and recommendations.

\section{A brief overview of the strategic spatial planning concept}

It is possible to come across many different sources defining the concept of strategic spatial planning in academic literature. The Webster Online Dictionary [1] defines strategic planning as "In organizational development, strategic management, and marketing, organizations employ strategic planning as a way to move toward their desired future states. It is the process of developing and implementing plans to reach goals and objectives. Strategic planning, more than anything else, is what gives direction to an organization" and expresses it under three headings:

- $\quad$ Situation - Where are we right now? How did we get here?

- $\quad$ Target - Where do we want to be?

- $\quad$ Path - How can we get there?

Albrechts [2] gives a general definition for strategic planning in the following manner: "Strategic planning could be considered a set of concepts, procedures and tools". It is necessary to apply to the more comprehensive definition of Healey [3] to switch to the strategic spatial planning concept. In her opinion "strategic spatial planning is a social process through which a range of people in diverse institutional relations and positions come together to design plan-making processes and develop contents and strategies for the management of spatial change". These definitions can be diversified, however it is deemed appropriate to leave it at this point for the scope of this study. However, those wishing to be informed in a more comprehensive manner are recommended to apply to the study of Albrecht [4] which provides many detailed definitions about this matter. Another point that also needs to be pointed out is that: Strategic planning is one of the important tools for cities to strengthen their position in the region within the framework of a holistic development policy and for them to be able to provide the sustainability of these positions.

\section{Strategic spatial planning approach of Turkey}

\subsection{Emergence of the need for strategic spatial planning}

Contrary to many countries, the concept of strategic spatial planning started to be pronounced very late in Turkey. Notwithstanding, this should not be interpreted 
as the fact that strategic planning is a very new concept. Strategic planning came on the agenda for the first time in Turkey approximately 20-25 years ago as metropolitan municipalities started to prepare their spatial plans with higher scales. However, these periods correspond to the years when other urban problems came up for Turkey. Illegal urbanization increased rapidly, zoning amnesties were implemented one after another in the 1980s and these years were recorded in the urbanization history of the country as the period in which existing problems in the space have been dealt with instead of reaching high scale urban goals and plans. In such periods, developing strategies for the future of the city is not a major problem for local governors; this is due to the fact that the future means the following elections and their target is to be reelected. This continued in the same manner until the beginning of the 1990s. Globalization started to be reflected in urban spaces as well in the 1990s and urban spaces underwent a rapid transformation. This transformation approached an uncontrollable position by the end of the 1990s. Decisions that need to be adopted by planning were replaced by the decisions of global capital about the selection of space. When the 2000s started, the wrong urban policies implemented in the country in the past necessitated restructuring in urban management. One of the fundamental topics of restructuring in the legal and administrative planes is about strategic planning. New legal arrangements place a lot of importance on strategic planning. Nevertheless, what strategic planning means in these arrangements has been a matter of argument and no real consensus exists with regard to it.

In summary, spatial planning was remembered once again due to three basic reasons: First of all, the fact that urban problems started to exceed the urban dimension introduced the need to deal with the problems at a higher scale. The method for this in a spatial sense is strategic planning. Secondly, this concept was perceived as a new concept within the framework of restructuring efforts in public administration and they found their place in the laws through the local governments reform package starting from the year 2004. In this respect, the concept of strategic planning was defined within basic codes such as the Code of Metropolitan Municipalities, the Code of Municipalities and the Code of Private Provincial Administrative Authorities. Also the institution that shall conduct strategic planning has been defined in these laws. Thirdly, new discussions emerged about the meaning of the concept of strategic planning. The fundamental problem here is the fact that the concept of strategic planning has been defined with different meanings in the codes referred to above. In other words, strategic planning has different meanings for all these units. Hence, circles interested in the subject are faced with the problem of redefining the concept of strategic planning or introducing new concepts for its meaning.

\subsection{Strategic plan mentality in Turkey}

It is necessary to analyze the matter from different perspectives in order to perceive the strategic plan approach of Turkey. This is due to the fact that legal and administrative perspectives and the academic perspective point in different directions. 


\subsubsection{The legal perspective}

The term strategy has a military origin in Turkey, just like in many other countries. However, we will not adopt a definition in this respect within the framework of this study. Starting from 2004, many laws were changed in the country. The new legal arrangements adopted strategic planning as a basic goal. Although the concept of strategic planning started to find a place in the Turkish literature in the 1980s, the definition of the strategic plan concept was included for the first time in the Bill of Basic Code of Public Administration. Although this bill is not yet legal, the definition in it is significant as laws referred to the above and called the Local Administration Reform Package have been prepared in conformity with the principles of this draft bill. A strategic plan is defined in the following manner in the bill: a strategic Plan is a plan including the medium and long term goals of public institutions and enterprises, their basic principles and policies, goals and priorities, performance criterion, the methods to be adopted in order to reach them and the distribution of resources. The concept mentioned here is an institutional strategy plan.

The Code of Metropolitan Municipalities, the Code of Municipalities and the Code of Private Provincial Administrative Authorities, which came into effect in accordance with the principles and approval of this law, mention spatial strategy plans. For instance, according to the Code of Metropolitan Municipalities, preparation of strategic plans of the metropolitan municipality and the preparation and implementation of master zoning plans of all scales ranging between $1 / 5.000$ and $1 / 25.000$ on the condition that they conform to the higher scale plan are among the duties and authorities of metropolitan municipalities. On the other hand, the Code of Municipalities refers to a strategic plan and performance program. According to this law, the municipalities and local governments are responsible for preparing a development plan and program and a strategic plan in conformity with the regional plan if there is any, within six months after the general elections and also for preparing an annual performance program before the beginning of each year. It is indicated that the strategic plan shall be prepared by also taking into consideration the opinions of universities, vocational chambers and the nongovernmental organizations related with the subject. Preparation of strategic plans is not mandatory for municipalities with populations of less than 50,000. The Code of Private Provincial Authorities on the other hand, mentions discussion of a strategic plan and adopting a decision about it among the duties and responsibilities of provincial general assemblies. According to the Code, The Provincial Environmental Order Plan prepared under the coordination of the governor, together with the metropolitan municipalities in metropolises, provincial municipalities and Private Provincial Administrative Authorities in other provinces is a kind of a higher scale plan, in which spatial goals are mentioned.

\subsubsection{Perspective of local governors}

In Turkey where urban problems increase rapidly, it would not be wrong to say that local governors perceive strategic planning as a savior or a magic wand. However, the major problem here is that the same local governors have also 
turned to the concept of "urban regeneration" with the same enthusiasm and justifications only about 2 years ago. Today, strategic planning activities started as a necessity imposed by the laws in many cities and especially in large metropolises. However, while these studies continue, the implementations of urban regeneration also continue rapidly in a manner independent from the general targets of strategic plan. Similarly, giant projects are imposed on large metropolises without caring about general planning targets and decisions and without seeking public consensus. Consequently, the danger of falling behind current implementations on the date when strategic plans are finished and the probability for this is very high. Another problem that the local governors face with respect to a strategic plan is about complexity of concepts. The concept of strategic planning is mixed most of the time with the concepts of long-range planning and comprehensive planning, and even the difference between goals and targets of spatial planning levels cannot be understood. Within this framework, it is not possible to conclude that local governors have adopted a strong, integrating and systematic planning approach. Göksu [5] suggests that strategic planning rather than spatial planning can be utilized as a significant program development technique in the public sector, on the basis of publicprivate sector cooperation. This approach is very feasible for local governments having a tendency towards a partnership model in all planning implementations and also explains the reason why the concept of a strategic plan has been internalized by local governments in such a short time.

\subsubsection{Academic perspective}

The situation is quite different in the academic perspective. It is not possible to say that today the perception of strategic planning by academic circles is parallel with the perspective of local administrators. Most local governors have included the concept of strategic plan in the program as they perceive it as an obligation imposed by the laws and prepare their strategic plans in a manner that is independent from other planning implementations that they perform; on the other hand, the academic circles focus on the need to keep all planning implementations as the parts of a certain system. It is not easy to find a single and clear definition for the concept of strategic planning in the academic studies conducted in Turkey as in many other countries. Notwithstanding, it is possible to find clues in the academic literature, which will help understand strategic planning. Göksu [5] indicates that the clearest expression of strategic planning should focus on the process of selection of strategic actions aimed at getting results. Camur [6] notes that strategic planning is not a package program and emphasizes that a strategic plan, which has been prepared well, may not lead to the consequences expected under unique conditions. With this emphasis, it is possible to suggest that the concept of strategic spatial planning is unique for locations. However, it should be noted that a strategic plan should adopt certain common and basic principles in terms of method and system for coordination at the country level. According to Özaydın [7] this includes focusing on specific choices of a location in order to acquire a new structure for the city. Özaydin, with this suggestion, mentions own choice of the places and refers to 
"uniqueness to a certain location", which supports Camur. Göksu [8] on the other hand states the comprehension of strategic planning as an important tool of development and emphasizes especially its feature of increasing competence by creating differences between cities. This point is evaluated among the most important opportunities presented by strategic planning.

\section{Research about strategic planning experiences in Turkey}

Surveys were conducted on 16 metropolitan municipalities in Turkey within the framework of this study, answers were received only from the metropolitan municipalities of Erzurum, Izmir, Gaziantep, Samsun and Kayseri. Notwithstanding, information exists with regard to the studies conducted by the Istanbul metropolitan municipality as its activities are followed up closely and it will also be included in this study.

\subsection{General information}

Strategic Planning studies are organized by the Head of the Research and Planning Coordination Department of Metropolitan Municipalities.

Istanbul Metropolitan Municipality: The Istanbul Metropolitan Municipality, included among the Municipalities within the framework of this study, started its strategic planning activities as the largest planning office of Europe with the Istanbul Urban Design and Metropolitan Area Planning Office that it established within its structure with a team of 500 people. There are plenty of academicians officiated in the three Urban and Regional Planning Departments located in Istanbul. Also an academician heads the office.

Izmir Metropolitan Municipality: The Master Zoning Plan Office for the whole of Izmir started its activities right after Istanbul. Strategic plans are conducted in this city in the Master Zoning Plan Office, which is the planning department within the structure of the metropolitan municipality.

Kayseri Metropolitan Municipality: It started strategic plan activities recently. A Strategic Planning Team comprising of 20 people was established with the cooperation of Strategic Planning Coordination Office and Strategic Planning Management within the structure of the Municipality. Joint studies are conducted with the State Planning Organization.

Samsun Metropolitan Municipality: Strategic planning activities have commenced very recently in Samsun just like Kayseri. Its activities are conducted through the Municipality Company SABEG.

Erzurum Metropolitan Municipality: It has not yet started any strategic planning activities. Preparations are in progress.

Gaziantep Metropolitan Municipality: It has not yet started any strategic planning activities. Preparation of a Strategic Plan within the scope of a Çevre Düzeni Planı for Gaziantep with a scale of 1/100 000 and Gaziantep Metropolitan Municipality Borders is included among the goals of the municipality for 2006 . 
Table 1.

\begin{tabular}{|l|l|l|l|l|}
\hline & $\begin{array}{c}\text { Population } \\
\text { (year } \\
2000)\end{array}$ & $\begin{array}{l}\text { Commencement } \\
\text { Date of } \\
\text { Strategic Plan }\end{array}$ & \multicolumn{1}{|c|}{$\begin{array}{c}\text { Organizational } \\
\text { Structure }\end{array}$} & $\begin{array}{c}\text { Municipality } \\
\text { Company conducting } \\
\text { the work }\end{array}$ \\
\hline Istanbul & 10018 & 2004 & $\begin{array}{l}\text { Istanbul Urban } \\
\text { Design and } \\
\text { Metropolitan } \\
\text { Area Planning } \\
\text { Office }\end{array}$ & BİMTAS \\
\hline Izmir & 335 & $\begin{array}{l}\text { Master Zoning } \\
\text { Plan Office for all } \\
\text { Izmir }\end{array}$ & \\
\hline Kayseri & 1060432 & 2005 & $\begin{array}{l}\text { Strategic Planning } \\
\text { Office }\end{array}$ & - \\
\hline Samsun & 363180 & 2005 & - & SABEG \\
\hline Erzurum & 937389 & - & & \\
\hline Gaziantep & 853513 & - & & \\
\hline
\end{tabular}

\subsection{Survey work}

The survey comprises a total of 8 questions. The questions were prepared to be open ended in order not to impose any restrictions and common inferences were made from the answers received. This study does not aim to make any numerical analysis. The aim is to display the common acceptances of municipalities about a strategic plan within the framework of the answers received; hence to make a generalization about strategic planning approaches in this respect. It was observed that the municipalities had not clarified their answers for some questions, had sometimes provided answers that was not included within the scope of the question or that sometimes the correct answers had been given when in the answers of other questions. For this reason, there had been a need to make a selection between answers or to exchange them with each other.

It is possible to analyze the 8 questions taken up within the scope of this study under 3 groups:

\begin{tabular}{|c|c|c|}
\hline I. Group Questions & II. Group Questions & III. Group Questions \\
\hline $\begin{array}{l}\text { Questions with regard to } \\
\text { the Strategic Plan } \\
\text { Approaches }\end{array}$ & $\begin{array}{lr}\text { Questions aimed } & \text { at } \\
\text { Opportunities } & \text { and } \\
\text { Expectations } & \text { and } \\
\text { Threats of Strategic } & \text { Plan }\end{array}$ & $\begin{array}{l}\text { Questions aimed at } \\
\text { Organization } \\
\text { Implementation }\end{array}$ \\
\hline $\begin{array}{l}\text { 1. Briefly describe your } \\
\text { vision for the city. }\end{array}$ & $\begin{array}{l}\text { 4. What are the most } \\
\text { important opportunities } \\
\text { and expectations that the } \\
\text { study of Strategic Plan } \\
\text { shall present to the city? }\end{array}$ & $\begin{array}{l}\text { 6. How do you organize } \\
\text { participation to strategic } \\
\text { planning activities? }\end{array}$ \\
\hline $\begin{array}{l}\text { 2. What meaning does } \\
\text { strategic plan have in } \\
\text { your opinion? }\end{array}$ & $\begin{array}{l}\text { 5. Do you think that } \\
\text { strategic plan can form a } \\
\text { threat for the city? }\end{array}$ & $\begin{array}{l}\text { 7. To what extent can you } \\
\text { reflect the planning } \\
\text { activities of district } \\
\text { municipalities in the } \\
\text { strategic plan? }\end{array}$ \\
\hline
\end{tabular}




\begin{tabular}{|l|l|l|}
\hline $\begin{array}{l}\text { W. What are the basic } \\
\text { goals of the strategic } \\
\text { plan that you conduct? }\end{array}$ & $\begin{array}{l}\text { 8. What are the major } \\
\text { reasons for you not to have } \\
\text { initiated any strategic } \\
\text { planning activities so far? } \\
\text { (For municipalities that } \\
\text { have not conducted) }\end{array}$ \\
\hline
\end{tabular}

\section{Assessment of group questions}

Vision for the city: The question that the participants underwent a complexity of concepts has been in defining the vision for the city. It was observed that at some points they defined their goals instead of their vision or defined their vision aimed at the municipality rather than the city. Their lack of a clear and unique vision for the city has been determined as the common characteristic of all municipalities. When all the answers selected and grouped are analyzed, a common vision for the city, for all municipalities can be put forward in the following manner: A sustainable city with a strong economy and a well organized administration, which is healthy, secure, contemporary, attractive for investors, carrying its historical, cultural and environmental values to the future, attaching importance on social justice, egalitarian and placing importance on cultural variety.

Meaning of strategic plan: When the answers given were reviewed, it was observed that strategic spatial planning had in fact been defined correctly by all municipalities. Answers such as "the action and policy guide necessary to reach goals and targets", "a road map for the journey between where we stand and where we wish to be", "an opportunity for change, the most valid administrative model for being successful in variable and uncertain environments ", "the long term and high quality administrative tool for the journey between the existing position of an institution and where it wishes to reach", "a strong set of decisions to establish a macro plan providing an opportunity for the healthy development of the city as a whole".

Basic goals: Institutional and social capacity development, governance development, social welfare and improvement of employment, balanced use of resources and making teamwork effective are included among the common basic goals of all municipalities. Besides these common answers such as establishing investment centers with multiple sectors, providing spatial justice, effectiveness in the process of planning and implementation, democracy preserving social awareness and the ability to compete were also received.

\section{Assessment of group questions}

Opportunities and expectations: The answers given for the opportunities and expectations that strategic planning would provide for the city show differentiation between cities. While the Metropolitan Municipality of Samsun emphasized participation, accountability, governance and effective use of resources, the Metropolitan Municipality of Izmir perceives planning for the whole area in general and the reflection of sector diversity into the space as the most important opportunity. The Metropolitan Municipality of Kayseri 
emphasized urban spaces that could be lived, provision of urban standards close to ideal, making green areas predominant and establishing harmony between construction and cultural heritage.

Threats: None of the municipalities having taken part in the survey perceive strategic planning as a threat.

\section{Assessment of group questions}

Organizing participation: The answers received reveal that the municipalities have different approaches about organization of participation. Notwithstanding the foregoing, it is pleasing to see that the comprehension of a participatory planning has been adopted by all municipalities. Municipalities generally organize participation by partner analysis, search conferences, evaluation meetings and meeting with representatives from different units. In this way, local governments, nongovernmental organizations, different public institutions, some private institutions and universities participate in the process. No efforts aimed at direct participation of the population into strategic planning were included in the answers. Only the Metropolitan Municipality of Kayseri indicated that they have conducted a survey for the urban population about the subject.

Participation of district municipalities: The metropolitan municipalities of Istanbul, Izmir and Samsun indicated that the district municipalities would always be present in the process of strategic planning and that coordination would continue. However, the municipality of Kayseri indicated that they have sought the opinion, thoughts and suggestions of district municipalities within the scope of partner analysis but did not give any clues with regard to the continuation of coordination.

Reason for not making a strategic plan: The reason for the Erzurum and Gaziantep Metropolitan Municipalities not having prepared a strategic plan until date are almost the same. Urgent projects with priority originating from the needs of cities have averted strategic plans until date.

\section{Conclusion and assessment}

The municipalities analyzed within the framework of the study provide the opportunity to make definite determinations about the approach to strategic planning in Turkey. The following determinations can be made within this framework:

The legal basis of strategic planning has been established in Turkey. The metropolitan municipalities have started their preparations within the framework of this legal basis. Most of the municipalities did not include making strategic plans in their programs before strategic plan became a legal requirement. The municipalities having closely understood the meaning of strategic planning are not successful enough about creating a vision for the city. However, their goals are quite clear. Each municipality conducts strategic planning activities with a different institutional organization model. In principle, they have adopted a 
common attitude about participation. However, their participation models and partners are quite different from each other.

Consequently, we can conclude that although Turkey has taken a giant step in this respect during the last two years that however the concept of strategic planning had not been internalized sufficiently by the municipalities. Although the meaning of strategic plan has been understood, we observe that in practice decisions coming from high officials are adopted, sectional urban transformation implementations are adopted, and goals to be foreseen by strategic plan are neglected by giant projects during implementations. Within this framework, Turkey is passing through a stage in which our municipalities and especially local governments have to act in a very sensitive manner.

\section{References}

[1] Webster Online Dictionary

[2] Albrechts L., 2004. Strategic (spatial) Planning Re-Examined, Environment and Planning B: Planning and Design, Vol. 31:743-758

[3] Healey P., 1997. An Institutional Approach to Spatial Planning, in P. Healey, A. Khakee, A. Motte, B. Needham (1997), Making Strategic Spatial Plans, Innovation in Europe, London UCL Press, pp. 21-36

[4] Albrechts L., 2005. Strategic (Spatial) Planning Revisited (an extended version of [2], new Policies and Strategies in Planning, $29^{\text {th }}$ Colloquium of November $8^{\text {th }}$, World Urbanization Day, Istanbul, pp.xxv-xliii

[5] Göksu S., 2006. Strategic Planning: Is it a Renewal of Faith or Privatization of Planning?, Urban Agenda No: 7, pp. 64-67

[6] Camur K., 2006. What is Strategic Planning? Opportunities and Risks of Physical Space in Planning, Urban Agenda No: 7, pp. 82-87

[7] Özaydın L., 2005. Comprehensible Strategic Planning within the Framework of Spatial Modeling, New Policies and Strategies in Planning: Risks and Opportunities; $29^{\text {th }}$ Colloquium of November $8^{\text {th }}$, World Urbanization Day, Istanbul, pp. 613-617

[8] Göksu F., 2005. Will Strategic Planning Approach be a Tool for the Establishment of a New Urban Order?, New Policies and Strategies in Planning: Risks and Opportunities; $29^{\text {th }}$ Colloquium of November $8^{\text {th }}$, World Urbanization Day, Istanbul, pp. 607-612 